\title{
Online Purchase: A Study of Generation Y in Malaysia
}

\author{
Lim Ying San ${ }^{1}$, Azizah Omar $^{2} \&$ Ramayah Thurasamy ${ }^{2}$ \\ ${ }^{1}$ Multimedia University, Melaka, Malaysia \\ ${ }^{2}$ Universiti Sains Malaysia, Penang, Malaysia \\ Correspondence: Lim Ying San, Faculty of Business, Multimedia University, Jalan Ayer Keroh Lama, 75450 \\ Melaka, Malaysia. Tel: 606-252-3528. E-mail: lim.ying.san@mmu.edu.my
}

Received: March 10, 2015

Accepted: April 27, 2015

Online Published: May 25, 2015

doi:10.5539/ijbm.v10n6p298

URL: http://dx.doi.org/10.5539/ijbm.v10n6p298

\begin{abstract}
Internet had changed the way businesses do business and the way consumers purchase the goods and services. With internet, the consumers can conduct their online shopping without hassle. Among all the internet users, Generation $\mathrm{Y}$ is the group of consumers who actively involved in online purchase. The total online purchase is expected to hit USD1.7 trillion by year 2015. However, in the developing country like Malaysia, the growth in online purchase is still relatively slow compare to the global trend. This aim of this study is to understand the purchase behaviour of Generation Y in Malaysia. The results of the study reveal that Malaysian Generation Y is not ready for online purchase because most of them are still having doubts on the website trust when they come to online purchase.
\end{abstract}

Keywords: generation Y, online purchase

\section{Introduction}

\subsection{Introduce the Problem}

Technology developments have improved customers' information accessed via various media methods such as print, broadcast and electronic media comprising the Internet. Among these methods, the Internet has become a highly used medium for businesses and service providers in communicating information and delivering products and services to customers. According to Turban, Lee, King, Liang and Turban (2009), the Internet is a useful tool for dispersing information to customers as it is being flexible, open, informal, and interactive. With the presence of Internet, latest information can be dispatched to customers speedily, 24 hours a day, seven days a week regardless of geographical location.

The benefits of the Internet have led many people attached to the internet. Businesses started to incorporate Internet applications in their business operations (Alba et al., 1997), and consumers started to start their online purchase via internet. According to Retail Research (2012), in Europe, more than $71 \%$ of European has shopped online and the e-commerce market was around $£ 101,840$ million in year 2011. Also, the e-commerce market in United States in year 2013 is around USD 312 billion (e-Marketers, 2014). The e-commerce market is anticipated will continue to grow in the future, e-marketers (2014) reported that global e-commerce market anticipated will exceed USD1.7 trillion by year 2015. Generation Y believed is the biggest group of people who utilised the internet in online purchase and contributed to the growth in e-commerce market.

Despite the growth in using Internet among Generation Y, however, the growth in online purchase is not in line with the growth internet usage among generation Y. According to a report by ACNielsen, out of the segment of people who purchased goods and services online in Malaysia in 2010, only 21.2percent of them are aged between 18 and 29 (Generation Y). This purchase statistics is relatively low compared to the Generation Y in other developed country such as United Kingdom (44percent). Also, according to Kok (2014), most of the Malaysian still felt reluctant to purchase online due to reasons such as security and privacy.

In order to better understand the online purchase market in Malaysia, the main objective of this study is to understand the online purchase among Generation $\mathrm{Y}$ in Malaysia. 


\section{Literature Review}

\subsection{Online Purchase in Malaysia}

The rise of Internet penetration in Malaysia has created new phenomena of consumers' attention to online purchasing. Online purchasing is getting popular and growing well in Malaysia. A recent study by ACNielsen and Paypal (Marketing Interative.com, 2011) depicts that online purchasing in Malaysia has recorded transactions worth RM1.8 billion in 2011 with the estimation of 1.1 million online shoppers. This figure is 70 percent higher than that recorded in the previous year. Items most frequently purchased online are travel-related products such as flight tickets and hotel accommodation (RM4.35 million), followed by financial products and services (RM3 million) and entertainment and leisure (RM2 million). Online purchasing activity is expected to involved transactions worth RM50 million in the year 2014.

\subsection{Generation $Y$}

Generation $\mathrm{Y}$ is a cohort of people born immediately after Generation $\mathrm{X}$, and it is referred to the dot.com generation, eco boomers and millionaires. While there are many discrepancies and debates on the age range of Generation Y, many studies have accepted Generation Y to be those born between 1978 and 1994 (Christine, 2000; Kotler \& Armstrong, 2010, p 98; Solomon, Dann, Dann \& Russell-Bennett, 2007, p.477). which is also held true in the Malaysian context (Evelyn, Eva \& Robin, 2011; Pricewaterhouse Coopers, 2009).

In Malaysia, Generation Y accounts for 11 million people in 2010 which is $40 \%$ of Malaysia's population (Department of Statistics Malaysia, 2011). Compared with other generations, Generation Y makes up the largest segment of Malaysia's population. Based on Com Score's (2009) categorization of Malaysian's internet population in Malaysia based on age, 38\% were 15-24 years old, 26\% were 26-35 years old, $23 \%$ were aged between 36-44 years old and 9\% from the age of 45-54 and 5\% aged 55 and above. Based on those statistics, the majority of the Internet population in Malaysia comprised generation Y (49\%), which is 15-35 years old (Com Score, 2009).

\subsection{The Characteristics of Generation $Y$}

The most interesting and significant characteristic of Generation $\mathrm{Y}$ is that they are technology- savvy (Ang, Leong \& Lee, 2009; Kumar \& Lim, 2008; Martin, 2005) and highly dependent on complex technology (Evelyn, Eva \& Robin, 2011). Generation Y is a heavy user of the Internet, willing to accept new technologies and has the ability to establish and sustain close relationships with others via the Internet (Kumar \& Lim, 2008; Syrett \& Lammiman, 2004).

Another significant characteristic of Generation $\mathrm{Y}$ is its high purchasing power compared with other generations (Ang et al., 2009; Farris et al., 2002) and eagerness to participate in online purchasing. Generation Y are familiar with the Internet usage and more receptive to the adoption of technological innovations (Kotler \& Armstrong, 2010, p. 98; Pricewaterhouse Coopers, 2009). They are very comfortable with online and mobile activities as well (Jones \& Leonard, 2008; Pricewaterhouse Coopers, 2009).

According to Retail Research (2012), Generation Y spending power is high, which is almost 200 billion USD a year. In term of factors affecting their decision to purchase, Generation $Y$ focuses on product value before purchasing any item or service from any seller (An Oracle white paper, 2009). This generation will not worry about debts and they will just spend it when they have income (Aquino, 2012). The same phenomena happened in Malaysia Generation Y, according to OCBC, Generation Y has characteristic of buy-now-pay-later behaviour, this created a market opportunity for this market segments (The Star, 2013).

In term of branding, Generation Y sees a reputable brand as an indicator of one's status and is therefore willing to pay extra for a preferred reputable brand (Farris, Chong, \& Dunning, 2002; O'Cass \& Choy, 2008). In addition, according to Aaker (1997), branding is even more important in Generation Y as this generation use brand to express themselves.

In terms of loyalty, bearing in the mind that Generation $Y$ has been exposed to various options and choices in purchasing products or services (Evelyn et al., 2011), this group of consumers is seen to be less loyal to one provider compared with other generations (Greene, 2004; Lazarevic, 2012). However, a study from Oracle indicates that Generation Y is loyal, but only to the brands which can match its interest. Thus, it is important for a company to in still in Generation Y, a sense of commitment and cohesion (An Oracle White Paper, 2009).

\section{Method}

In order to understand the online purchase behaviour of Generation $\mathrm{Y}$ in Malaysia, questionnaires were distributed to the Generation Y via facebook. The questionnaire was divided into 2 session with demographic 
information in session A and online purchase behavior in session B.

The facebook groups were chosen by referring to Alexa.com (Alexa.com), and Social Bakers (Social Bakers.com), which provides the list of the top e-commerce websites and Facebook site in Malaysia in 2013. After the Facebook groups were identified, the questionnaires were sent to the different Facebook groups' moderators and the individual respondents.

Facebook were used because the total Facebook population in Malaysia reached 12 million, which meant that 68 percent of Malaysia's internet population owned a Facebook account (Internet World Stats, 2014). In addition, Malaysians also spent most of their time on social networks, which contributed to 32.1 percent of total time spent online (Comscore, 2011). Hence, Facebook is a good platform to reach potential respondents.

\section{Results and Discussion}

A total of 3600 questionnaires were distributed during the data collection period and 557 respondents responded to the questionnaire which indicates the response rate of 15.5 percent. This response rate was relatively low compared to the studies using face to face questionnaires. However, the response rate is acceptable especially in online surveys (Sweep, 2006).

\subsection{Demographic Profile of the Respondent}

The profile of the respondents in the study is shown in Table 1 below. Out of 424 usable data, 43.9percent of the respondents were male and 56.1 percent of respondents were female. All the respondents in the study were Generation Y aged between 19 to 35 years old. 36.1 percent of the respondents were grouped between 27 to 30 years old, followed by 33.7 percent of respondents aged 23 to 26.16 percent of respondents were aged 19 to 22 and 14.2 percent of respondents age 31-35. All respondents in the study were Malaysian.

The majority of the respondents had income less than RM1000 (31.8 percent), followed by income between RM3001 to RM5000 (28.8 percent), RM1001-RM3000 (23.6 percent), Rm5001-RM7000 (9 percent) and more than RM7000 (6.8 percent) respectively.

Table 1. Respondents' demographic profile

\begin{tabular}{llll}
\hline & & Frequency & Percentage \\
\hline \multirow{3}{*}{ Gender } & Male & 186 & 43.9 \\
& Female & 238 & 56.1 \\
& $19-22$ & 68 & 16 \\
& $23-26$ & 143 & 33.7 \\
\multirow{4}{*}{ Income } & $27-30$ & 153 & 36.1 \\
& $31-35$ & 60 & 14.2 \\
& Less than RM1000 & 135 & 31.8 \\
& RM1001-RM3000 & 100 & 23.6 \\
& RM3001-RM5000 & 122 & 28.8 \\
& RM5001-RM7000 & 38 & 9 \\
& More than RM7000 & 29 & 6.8 \\
\hline
\end{tabular}

\subsection{Respondents' Online Purchasing Behaviour}

Table 2.0 shows the online purchasing behaviour of the respondents. On average, 30.2 percent of the respondents spent 2-3 hours online in one day. All the respondents had purchased online before. The majority of them had been buying online for 1-3 years (45.5 percent). 59.2 percent of respondents had experienced of online purchased in less than one month. In terms of purchasing frequency, 35.8 percent of the respondents purchased product or services online 1-2 times in the past 6 months. In terms of number of items purchased online, most of the respondents purchased 1-2 items every time they purchased online (34.7 percent). In terms of money spent, 35.6 percent of the respondents spent less than RM 100 every time they purchased online.

The respondents online purchase behaviour showed that Malaysia's Generation Y is familiar with cyberspace and started to make use of it for online purchase. However, their spending (in term of money and time) is relatively low compared to Generation Y in other countries. According to Tech in Asia (2011), individual Singaporeans spent around RM 3730 per year shopping online equivalent to RM 300 per month. Similarly, according to Emarketer (2013), it is common for Generation Ys in United States to spend at least one hour a day shopping online. Compared with the statistics of online purchase from others countries, Malaysia's Generation Y 
are much less involved in online shopping because most online users in Malaysia have a- "wait and see" attitude regarding online shopping, due to a lack of confidence in this new purchasing method (Marketing-Interative.com, 2011).

Most of the respondents had the thoughts of trust is the most important factors when they choose their online purchase website (307), followed by security (278), service offered (255), reputation (232), experience of purchase (227) and others such as price and quality of the products, usefulness of the website and convenience. This finding showed that despite their familiarity with online purchasing, most Generation Ys still have doubts about websites they choose to use for online purchase. Most Generation Ys rank trust and security as two of the most important factor in choosing the online purchase website. This finding is consistent Paypal report that described security as the main worries of online users in Malaysia regarding their online purchases. (Kok, 2014; Ho, 2011). Therefore, finding a trustable website becomes an important factor in online purchasing. However, since the online market in Malaysia is still lacking trustworthy and reputable website, most online users in Malaysia prefer to purchase products or services from the foreign websites such as taobao.com, agoda.com, eBay and others. Similar findings have been identified by PayPal which reported that foreign websites from China, the United States, and Taiwan are becoming popular for Malaysians wanting to shop online (Kok, 2014).

Table 2. Respondents' online purchasing behaviour

\begin{tabular}{|c|c|c|c|}
\hline & & Frequency & Percentage \\
\hline \multirow{4}{*}{ On average, how many hours do you spend online in one day? } & $1-2$ hours & 65 & 15.3 \\
\hline & 2-3 hours & 128 & 30.2 \\
\hline & 5-6 hours & 93 & 21.9 \\
\hline & More than 6 hours & 138 & 32.5 \\
\hline \multirow{6}{*}{$\begin{array}{l}\text { Which factors are important to you when you choose your online purchasing } \\
\text { website? ( may choose more than one option) }\end{array}$} & Security & 278 & \\
\hline & Trust & 307 & \\
\hline & Experience of purchase & 227 & \\
\hline & Service offered & 255 & \\
\hline & Reputation & 232 & \\
\hline & Other & 22 & \\
\hline \multirow{4}{*}{ How long have you been purchasing online? } & Less than 1 year & 98 & 23.4 \\
\hline & 1 to 3 years & 193 & 45.5 \\
\hline & 3 to 5 years & 77 & 18.2 \\
\hline & More than 5 years ago & 56 & 13.2 \\
\hline \multirow{3}{*}{ When was the last time you made a purchase online? } & Less than 1 month ago & 251 & 59.2 \\
\hline & 1- 3 months ago & 126 & 29.7 \\
\hline & 4-6 months ago & 47 & 11.1 \\
\hline \multirow{4}{*}{$\begin{array}{l}\text { How many times have you purchased product or services online in the past } 6 \\
\text { months? }\end{array}$} & $1-2$ times & 152 & 35.8 \\
\hline & 3-4 times & 116 & 27.4 \\
\hline & 4-5 times & 53 & 12.5 \\
\hline & 6 times and above & 102 & 24.1 \\
\hline \multirow{4}{*}{ How many items have you purchased online in the past 6 months? } & $1-2$ items & 147 & 34.7 \\
\hline & 3-4 items & 83 & 19.6 \\
\hline & $5-6$ items & 60 & 14.2 \\
\hline & 7 items and above & 134 & 31.6 \\
\hline \multirow{4}{*}{ On average, how much do you spend every time you purchase online? } & Less than RM 100 & 151 & 35.6 \\
\hline & RM 101-RM200 & 148 & 34.9 \\
\hline & RM 201-RM 300 & 47 & 11.1 \\
\hline & RM 301 and above & 78 & 18.4 \\
\hline
\end{tabular}

Table 3 shows the respondents most frequently purchased items using online purchasing. Plane tickets were the most popular item purchased by respondents (140), followed by clothes (89) and entertainment items (42). The respondents favourite purchase was consistent with the report from AcNeilson and Paypal (Marketing Interative.com, 2011) which reported that the most frequently purchased item using online purchasing in Malaysia are travel-related products such as flight tickets and hotel accommodation (RM4.35 million), followed 
by financial products and services (RM3 million) and entertainment and leisure products and services (RM2 million). Other than the items listed above, the respondents also purchased kitchen accessories, baby and nursing products, shoes, food, toys and camera products using online purchasing.

Table 3. Most frequently purchased item

\begin{tabular}{llll}
\hline & \multicolumn{3}{c}{ Ranking (frequency) } \\
& First & Second & Third \\
\hline Accessories (apparel) & 36 & 63 & 47 \\
Air Ticket & 140 & 72 & 53 \\
Books & 8 & 18 & 21 \\
Clothes & 89 & 72 & 44 \\
Entertainment & 42 & 47 & 46 \\
Financial products and services & 6 & 11 & 16 \\
Flowers & 2 & 6 & 8 \\
Health and beauty products & 32 & 33 & 41 \\
IT products and accessories & 33 & 48 & 53 \\
Travelling services & 17 & 41 & 46 \\
Others & 19 & 10 & 26 \\
\hline
\end{tabular}

Table 4 shows the respondents most preferred websites in online purchasing. It is clearly indicates that Airasia.com is the most preferred website used by the respondents (116), followed by taobao.com (68) and facebook.com (62). According to the Paypal report, airline tickets are the most popular items purchased by Generation Y because they are digital products, not physical goods. The purchase of digital products has less risk of getting an incorrect product from the seller compare to physical product (Kok, 2014).

Table 4. Respondents favourite online purchasing website

\begin{tabular}{|c|c|c|c|}
\hline & \multicolumn{3}{|c|}{ Ranking (frequency) } \\
\hline & First & Second & Third \\
\hline Agoda.com & 16 & 49 & 38 \\
\hline Airasia.com & 116 & 63 & 51 \\
\hline Alibaba.com & 4 & 5 & 7 \\
\hline Amazon.com & 2 & 9 & 10 \\
\hline Apple.Inc & 2 & 7 & 13 \\
\hline eBay & 11 & 11 & 16 \\
\hline facebook.com & 62 & 50 & 39 \\
\hline gsc.com.my & 27 & 44 & 41 \\
\hline groupn.my & 40 & 59 & 40 \\
\hline JomNiaga & 2 & 1 & 3 \\
\hline Lazada.com.my & 6 & 6 & 6 \\
\hline lelong.com.my & 15 & 13 & 18 \\
\hline Malaysia Airlines & 8 & 10 & 21 \\
\hline Mudah.my & 17 & 23 & 17 \\
\hline taobao.com & 68 & 65 & 24 \\
\hline yahoo.com.my & 2 & 4 & 10 \\
\hline zalora.com.my & 5 & 12 & 16 \\
\hline Others & 22 & 17 & 25 \\
\hline
\end{tabular}

\section{Conclusion and Recommendations}

Online purchasing in Malaysia is still in infancy stage compared to other developed countries such as United States. Due to these, many online users and sellers are still observing the online market and they are not fully involving in it. This makes the growth of the online market in Malaysia is relatively slow compared to other developed countries. The results of the findings shows that Malaysian generation Y are conservative when they deal with online purchase. This can be observed from their online purchase behaviour in the study. 
Online purchase is in fact a trend now in the global market. Hence, it is an opportunity for the business people to utilise this opportunity to serve the Generation $\mathrm{Y}$ and tap this untapped market in Malaysia. It is suggests that the online seller should start to participate in online market by offering the ecommerce website for the Generation $\mathrm{Y}$ to shop. In order to encourage the Generation Y to shop with the seller, the sellers have to find ways to build the consumers trust on the website. Once the trust is formed, it will subsequently encourage the Generation $Y$ to purchase online and the growth of online purchase market in Malaysia. Example, seller can have more security and privacy tools in their website to assists the Generation $\mathrm{Y}$ trust formation when purchasing online. In addition, peer to peer discussion forum and real time interaction with sellers should be formed in the website so the buyers can check with others members before they conduct the shopping activities. This can increase their confidence level before they decided to shop using the specific website.

\section{Direction for Future Studies}

Since this is a descriptive study, future study should continue to study the possible factors affecting the Generation $\mathrm{Y}$ online purchase behavior by referring to theories and models in order to better understand the buying behavior of Generation $\mathrm{Y}$ in Malaysia.

In addition, comparison studies can be conducted to compare the online purchase behavior of Generation $\mathrm{Y}$ in various countries. Countries that can be included are developed countries such as Unites States, Taiwan, Korea or Japan or developing countries such as Thailand and Indonesia. This will give a clearer picture on the online purchase situation in Malaysia.

\section{References}

Aaker, J. L. (1997). Dimensions of brand personality. Journal of Marketing Research, 34(3), 347-356.

Alba, K. L., Weitz, J. B., Janisewski, C., Lutz, R., Savoyer, A., \& Wood, S. (1997). Interactive home shopping: Consumer, retailer and manufacturer incentives to participate in electronics marketplace. Journal of Marketing, (July), 38-53.

An Oracle White Paper. (2009). Generation Y: the builders of tomorrow business. Oracle financial service, September, Oracle. Retrieved from http://www.oracle.com/us/industries/financial-services/gen-y-builders-wp-163349.pdf

Ang, E., Leong, H. Y., Lee, K. S. (2009). Gen-Y Technically Savvy. Retrieved from http://biz.thestar.com.my/news/story.asp?file=/2009/10/24/business/4771567\&sec=business

Aquino, J. (2013). Generation $Y$, the next generation of spender. Retrieved from http://www.destinationcrm.com/Articles/Editorial/Magazine-Features/Gen-Y-The-Next-Generation-of-Spen ders-79884.aspx

Christine, S. (2000). Clothing E-tailers target Gen Y shoppers with banner ad. Adweek, 41(20).

Com Score. (2009). Retrieved from http://www.comscore.com/

Com Score. (2011). Retrieved from http://www.comscore.com/fre/Press_Events/Press_Releases/2011/10/Social_Networking_Accounts_for_On e_Third_of_All_Time_Spent_Online_in_Malaysia

Department of Statistics Malaysia. (2011). Access on February 2012. Retrieved from http://www.statistics.gov.my

eMarketer. (2014). Retrieved from http://www.emarketer.com/Article/Global-B2C-Ecommerce-Sales-Hit-15-Trillion-This-Year-Driven-by-Gro wth-Emerging-Markets/1010575

Evelyn, T. B. H., Eva, L. W. L., \& Robin, C. (2011). Generation y and choice of mobile service provider: A study on their purchasing decisions in choosing a mobile service provider. 2nd International Conference on Business and economic Research (2nd ICBER 2011) Proceeding.

Farris, R., Chong, F., \& Dunning, D. (2002). Generation Y: Purchasing power and implications for marketing. Academy of Marketing Studies Journal, 6(2), 89-101.

Greene, P. (2004). Generation Y-Behind the housewares buy. Housewares market watchs, International Housewares associations.

Ho, S. (2011). Malaysians spent RM1.8 bil shopping online in 2010. Retrieved from $\mathrm{http}: / /$ thestar.com.my/news/story.asp? file $=/ 2011 / 4 / 22 /$ nation $/ 8534221 \& \mathrm{sec}=$ nation

Internet Words Stat. (2014). Retrieved from http://www.internetworldstats.com on 
Jones, K., \& Leonard, L. N. K. (2008). Trust in consumer to consumer electronic commerce. Information and Management, 45, 88-95.

Kok, S. F. (2014). 70\% of Malaysian conducted online shopping once in a month. Sin Chew Jit Poh, 26.

Kotler, P., \& Armstrong, G. (2010). Principles of Marketing (13th ed.). Pearson, Prentice Hall.

Kumar, A., \& Lim, H. (2008). Age differences in mobile service perceptions: Comparison of Generation Y and baby boomers. Journal of Services Marketing, 22(7), 568-577. Publisher: Emerald Group Publishing Limited.

Lazarevic, V. (2012). Encouraging brand loyalty in fickle generation Y consumers. Young Consumers: Insight and Ideas for Responsible Marketers, 13(1), 45-61.

Marketing Interative.com. (2011). Retrieved from http://marketing-interactive.com/news/25946

Pricewaterhouse Cooper. (2009). Malaysia's Gen-Y unplugged. Retrieved from http://www.geniustribes.com/resources/gen-yMal.pdf

Retail Research. (2012). Online Retailing: Britain and Europe. Retrieved from http://www.retailresearch.org/onlineretailing.php

Solomon, M. R., Dann, S., Dann, S., \& Russell-Bennett, R. (2007). Consumer behaviour:Buying, having, being. Frenchs Forest, NSW: Pearson Education.

Syrett, M., \& Lammiman, J. (2004). Advertising and millennials. Young Consumers: Insights and Ideas for Responsible Marketers, 5(4), 62-73.

Techinasia. (2011). The Stat and fact in online shopping in Singapore. Retrieved from http://www.techinasia.com/the-stats-and-facts-of-online-shopping-in-singapore/

The Star. (2013). More bank trying to tap a bigger piece of generation $\mathrm{Y}$ Retrieved from http://biz.thestar.com.my

The Statistics Portal. (2014). Millennial online/wireless shopping habits in United States in 2013, by gender. Retrieved

from http://www.statista.com/statistics/281469/generation-y-online-wireless-shopping-habits-in-the-us/

Turban, E., Lee, J. K., King, D., Liang, T. P., \& Turban, D. (2009). Electronic commerce 2010 (6th ed.). Pearson Education.

\section{Copyrights}

Copyright for this article is retained by the author(s), with first publication rights granted to the journal.

This is an open-access article distributed under the terms and conditions of the Creative Commons Attribution license (http://creativecommons.org/licenses/by/3.0/). 